\title{
Selective DNA Strand Scission with Binuclear Copper Complexes: Implications for an Active $\mathrm{Cu}_{2}-\mathrm{O}_{2}$ Species
}

\author{
Sunita Thyagarajan ${ }^{\dagger}$, N. N. Murthy ${ }^{\dagger}$, Amy A. Narducci Sarjeant ${ }^{\dagger}$, Kenneth D. Karlin ${ }^{\dagger},{ }^{*}$, and \\ Steve E. Rokita ${ }^{*}{ }^{*}$ \\ $\dagger$ Department of Chemistry, Johns Hopkins University, Baltimore, Maryland 21218 \\ $\$$ Department of Chemistry and Biochemistry, University of Maryland, College Park, Maryland 20742
}

\begin{abstract}
A homologous series of binuclear copper(II) complexes $\left[\mathrm{Cu}^{\mathrm{II}}{ }_{2}(\mathrm{Nn})(\mathrm{Y})_{2}\right]^{2+}(\mathbf{1}-\mathbf{3})(\mathrm{n}=3-5$ and $\mathrm{Y}=$ $\left(\mathrm{ClO}_{4}\right)^{-}$or $\left.\left(\mathrm{NO}_{3}\right)^{-}\right)$were studied to investigate the intermediate(s) responsible for selective DNA strand scission in the presence of MPA/ $\mathrm{O}_{2}$ (MPA = 3-mercaptopropanoic acid). While the $\mathbf{N 3}$ complex does not react, the $\mathbf{N} \mathbf{4}$ and $\mathbf{N 5}$ analogues show comparable activity with strand scission occurring at a single-strand/double-strand junction. Identical reactivity is also observed in the alternate presence of $\mathrm{H}_{2} \mathrm{O}_{2}$. Spectroscopic and reactivity studies with $\left[\mathrm{Cu}_{2}{ }_{2}(\mathbf{N} 4)(\mathrm{Y})_{2}\right]^{2+}(2)$ and $\mathrm{H}_{2} \mathrm{O}_{2}$ are consistent with DNA oxidation mediated by formation of a side-on peroxodicopper(II) $\left(\mathrm{Cu}_{2}-\mathrm{O}_{2}\right)$ complex.
\end{abstract}

\section{Introduction}

Reagents for selective cleavage of nucleic acids have provided convenient tools for characterizing structure and dynamics of DNA and its assembly with proteins. Transition metal complexes are particularly useful in this application since they offer a rich variety of three dimensional structures and redox characteristics. ${ }^{1-3}$ Copper complexes possess biologically accessible redox potentials and demonstrate high nucleobase affinity, thus making them effective and highly popular as reagents for DNA oxidation and cleavage. ${ }^{1,4}$ Typically, these copper complexes are thought to form reactive intermediates upon association with dioxygen or hydrogen peroxide.

The interaction between copper complexes and dioxygen has been extensively studied as models for metalloenzymes. ${ }^{5,6}$ The observation and characterization of the copper-dioxygen complexes formed by $\mathrm{O}_{2}$ reaction with mono- and dinuclear copper(I) complexes has also yielded important information on mechanisms of substrate oxidation. ${ }^{5}$ These studies have recently been extended to nucleic acids. Multinuclear copper complexes efficiently promote selective and direct DNA strand scission in the presence of reducing agents (e.g. 3mercaptopropanoic acid (MPA)) and dioxygen. ${ }^{7}$ Results to date suggest that DNA is oxidized by an intermediate $\mathrm{Cu}_{2}-\mathrm{O}_{2}$ species, but no definitive evidence of this has been gathered. The role of such an intermediate became even more intriguing after an alternative but related binuclear copper complex $\left.\mathrm{Cu}_{2} \mathrm{II}_{2}\left(\mathrm{PD}^{\prime}-\mathrm{O}\right)\left(\mathrm{H}_{2} \mathrm{O}\right)_{2}\right]\left(\mathrm{ClO}_{4}\right)_{3} \cdot 2 \mathrm{H}_{2} \mathrm{O}\left(\mathrm{PD}^{\prime}-\mathrm{O}\right.$ is a phenolate containing binucleating ligand) was found to promote guanine oxidation rather than strand scission. 8 Both series of copper complexes selectively act at junctions of single- and doublestranded DNA despite their differences in oxidation chemistry. Thus, the choice of ligand may 
be used to control the type of copper intermediate formed under biomimetic conditions and ultimately the type of reaction promoted with DNA.

The well established properties of a third series of dicopper complexes $\left[\mathrm{Cu}_{2}(\mathbf{N n})\left(\mathrm{O}_{2}\right)\right]^{2+}(\mathrm{n}=$ $3-5$ ) has now provided the first opportunity to establish a correlation between $\mathrm{Cu}_{2}-\mathrm{O}_{2}$ structure and DNA oxidation. The $\mathrm{O}_{2}$-adducts of this series form a $\mu-\eta^{2}: \eta^{2}$ side-on bound peroxodicopper(II) core (Figure 1) at low temperature and in a non-polar solvent. ${ }^{9-11}$ The O$\mathrm{O}$ stretching frequencies observed by resonance Raman spectroscopy decrease from 765 to $741 \mathrm{~cm}^{-1}$ for $\mathrm{n}=3$ to 5 , and accompanying structural and spectroscopic changes are also evident. ${ }^{10,11}$ In this report, variations of the $\left[\mathrm{Cu}^{\mathrm{II}}{ }_{2}(\mathrm{Nn})\left(\mathrm{O}_{2}{ }^{2-}\right)\right]^{2+}$ core $(\mathrm{n}=3-5)$ are also shown to manifest themselves during oxidation of DNA as carried out using new dicopper(II), rather than dicopper(I), precursors 1-3 (Figure 1). The selectivity of complexes $\mathbf{2}$ and $\mathbf{3}$ are identical in the presence of either MPA/ $\mathrm{O}_{2}$ or $\mathrm{H}_{2} \mathrm{O}_{2}$. Both conditions lead to a common reactive peroxodicopper(II) species that is detected by UV-Vis spectroscopy and postulated to be responsible for DNA oxidative cleavage. By contrast, complex $\mathbf{1}$ does not show this behavior, probably since it does not form a similar peroxo-dicopper(II) complex under protic conditions.

\section{Experimental Section}

\section{Reagents and Materials}

All chemicals and solvents were purchased as reagent grade unless otherwise stated.

Oligodeoxynucleotides were purchased from Invitrogen Life Technologies. T4 kinase and its buffer were obtained from New England Biolabs and $\left[\gamma_{-}{ }^{32} \mathrm{P}\right]$ ATP $(3000 \mathrm{Ci} / \mathrm{mmol})$ was obtained from Amersham. Stock solutions of all reagents were prepared fresh daily. In addition, 3-mercaptopropionic acid (MPA) was titrated with Ellman's reagent to determine the free thiol concentration. ${ }^{12}$ Elemental analyses were performed by Desert Analytics, Tucson, AZ. X-Ray diffraction was performed at the X-Ray diffraction facility at the Johns Hopkins University with an Excalibur 3 diffractometer. Low temperature UV-Vis spectra were recorded with a Hewlett-Packard model 8453 diode array spectrophotometer equipped with a custom made quartz dewar filled with cold $\left(-78^{\circ} \mathrm{C}\right)$ methanol (maintained and controlled by a Neslab ULT-95 low temperature circulator). GC analyses were carried out on a HP-5890 Series II gas chromatograph using an Rtx-5 (Crossbonded 5\% diphenyl 95\% dimethyl polysiloxane) $30 \times$ $0.32 \mathrm{~mm}$ ID $\times 0.25 \mu \mathrm{M}$ film thickness and analyzed with a flame ionization detector connected to Peak Simple Chromatography Data System from SRI.

\section{Synthesis of Ligands N3-N5}

The ligands N3, N4 and N5 were synthesized according to published procedures. ${ }^{9-11}$

\section{$\mathrm{Cu}_{2}{ }_{2}(\mathrm{~N} 3)\left(\mathrm{H}_{2} \mathrm{O}\right)_{5}\left(\mathrm{ClO}_{4}\right)_{4}(1)$}

Complex 1 was synthesized by stirring a methanolic solution of $\mathrm{Cu}\left(\mathrm{ClO}_{4}\right)_{2} \cdot 6 \mathrm{H}_{2} \mathrm{O}(0.12 \mathrm{~g}, 0.40$ $\mathrm{mmol})$ with the $\mathbf{N} \mathbf{3}$ ligand $(0.10 \mathrm{~g}, 0.21 \mathrm{mmol})$ for 30 minutes at room temperature. The solution was filtered, and the solvent was removed from the filtrate in vacuo to yield complex $\mathbf{1}$ as a light blue powder in $70 \%$ yield. Anal: calcd. for $\left(\mathrm{C}_{31} \mathrm{H}_{52} \mathrm{Cl}_{4} \mathrm{Cu}_{2} \mathrm{~N}_{6} \mathrm{O}_{23}\right): \mathrm{C}, 32.47 ; \mathrm{H}, 4.57 ; \mathrm{N}$, 7.33. Found: C, 31.88; H, 3.79; N, 7.05.

\section{$\left[\mathrm{CuI}_{2}(\mathrm{~N} 4)\left(\mathrm{H}_{2} \mathrm{O}\right)_{4}\left(\mathrm{ClO}_{4}\right)_{4}\right](2)$}

Complex 2 was synthesized by stirring a methanolic solution of $\mathrm{Cu}\left(\mathrm{ClO}_{4}\right)_{2} \cdot 6 \mathrm{H}_{2} \mathrm{O}(0.17 \mathrm{~g}, 0.45$ $\mathrm{mmol})$ with the $\mathbf{N} 4$ ligand $(0.105 \mathrm{~g}, 0.23 \mathrm{mmol})$ for 30 minutes at room temperature. The solution was filtered, and the filtrate was concentrated and layered with ether. Blue crystals of complex $2(0.21 \mathrm{~g}, 91 \%)$ were collected and used for X-ray crystal structure analysis. UV-Vis (EtOH-CH $\left.\mathrm{CH}_{2} \mathrm{Cl}_{2}\right): 690 \mathrm{~nm}\left(160 \mathrm{M}^{-1} \mathrm{~cm}^{-1}\right), 770 \mathrm{~nm}\left(150 \mathrm{M}^{-1} \mathrm{~cm}^{-1}\right)$. Anal: calcd. for $\left(\mathrm{C}_{32} \mathrm{H}_{48} \mathrm{Cl}_{4} \mathrm{Cu}_{2} \mathrm{O}_{20}\right): \mathrm{C}, 34.74 ; \mathrm{H}, 7.59 ; \mathrm{N}, 4.3$. Found: $\mathrm{C}, 35.48 ; \mathrm{H}, 7.59 ; \mathrm{N}, 4.50$. 


\section{$\left[\mathrm{Cu}_{2}(\mathrm{~N} 5)\left(\mathrm{H}_{2} \mathrm{O}\right)_{2}\left(\mathrm{NO}_{3}\right)_{4}\right](3)$}

Complex 3 was synthesized by stirring an ethanolic solution of $\mathrm{Cu}\left(\mathrm{NO}_{3}\right)_{2} \cdot 6 \mathrm{H}_{2} \mathrm{O}(110 \mathrm{mg}, 0.47$ $\mathrm{mmol}$ ) with the $\mathbf{N 5}$ ligand $(120 \mathrm{mg}, 0.23 \mathrm{mmol})$ for 30 minutes at room temperature. The mixture was warmed briefly to $50^{\circ} \mathrm{C}$ and cooled to room temperature to yield a microcrystalline blue solid. This was filtered, and the solid was dried in air to provide the desired product in $86 \%(0.14 \mathrm{~g})$. Recrystallization of the solid from a mixture of $\mathrm{CH}_{3} \mathrm{CN}$ and $2 \%$ water via slow evaporation of the solvent produced light-blue needles suitable for X-ray crystal structure analysis. UV-Vis (EtOH plus a drop of $\left.\mathrm{H}_{2} \mathrm{O}\right): 660 \mathrm{~nm}\left(140 \mathrm{M}^{-1} \mathrm{~cm}^{-1}\right)$. Anal: calcd. for $\left(\mathrm{C}_{33} \mathrm{H}_{46} \mathrm{Cu}_{2} \mathrm{~N}_{10} \mathrm{O}_{14}\right): \mathrm{C}, 42.42 ; \mathrm{H}, 4.96 ; \mathrm{N}, 14.99$. Found: $\mathrm{C}, 42.53 ; \mathrm{H}, 4.75 ; \mathrm{N}, 14.74$.

\section{$\left[\mathrm{Cu}(\mathrm{MePY} 2)\left(\mathrm{ClO}_{4}\right)_{2}\left(\mathrm{CH}_{3} \mathrm{CN}\right)\right](4)$}

The mononuclear complex used in control studies was formed by adding MePY2 (200 mg, $0.82 \mathrm{mmol})$ in a solution of $\mathrm{Cu}\left(\mathrm{ClO}_{4}\right)_{2} \cdot 6 \mathrm{H}_{2} \mathrm{O}(310 \mathrm{mg}, 0.83 \mathrm{mmol})$ in $5 \mathrm{~mL}$ of $\mathrm{CH}_{3} \mathrm{CN}$. The resulting solution was stirred for 1 hour at room temperature, concentrated to $4 \mathrm{~mL}$ and then layered with ether. The solution was maintained at $-20^{\circ} \mathrm{C}$ overnight, filtered and dried under vacuum yielding a fine blue powder in $75 \%$ yield $(412 \mathrm{mg})$. Anal: calcd. for $\left(\mathrm{C}_{17} \mathrm{H}_{22} \mathrm{CuN}_{4} \mathrm{O}_{8}\right)$ : C, 37.45; H, 4.07; N, 10.28. Found: C, 37.93; H, 4.41; N, 10.63.

\section{Purification and Labeling of DNA}

Oligodeoxynucleotides were purified prior to use by denaturing ( $7 \mathrm{M}$ urea) polyacrylamide gel electrophoresis (PAGE) and subsequent elution by $50 \mathrm{mM} \mathrm{NaOAc}$ and $1 \mathrm{mM}$ EDTA (pH 5.2). The resulting solutions were extracted with phenol/chloroform, and the DNA was precipitated by addition of ethanol. DNA was then dried under reduced pressure and redissolved in distilled deionized water (17.9-18.1 M $\Omega$-cm). DNA concentrations were determined by absorbance at $260 \mathrm{~nm}$ and the $\varepsilon_{260}$ values supplied by the manufacturer. DNA was radiolabeled with $\left[\gamma_{-}{ }^{32} \mathrm{P}\right]$ ATP and T4 kinase according to the supplier. The $5^{\prime}-\left[{ }^{32} \mathrm{P}\right]$-labeled DNA was isolated after passage over a MicroBioSpin P-6 column (Bio-Rad).

\section{Copper Mediated Strand Scission}

For duplex DNA (OD1/OD2), 5'-[ $\left.{ }^{32} \mathrm{P}\right]$-labeled oligodeoxynucleotides ( $\left.90 \mathrm{nCi}, 5 \mathrm{pmol}\right)$ were alternatively mixed with their complementary strands $(7.5 \mathrm{pmol})$ in sodium phosphate $(10 \mathrm{mM}$, $\mathrm{pH} 7.5$ ) to yield $100 \mathrm{nM}$ duplex. DNA was then annealed by heating to $90^{\circ} \mathrm{C}$ followed by slow cooling to room temperature. Reaction was initiated at room temperature by addition of MPA $(100 \mu \mathrm{M})$ or $\mathrm{H}_{2} \mathrm{O}_{2}(2 \mu \mathrm{M})$ to the annealed DNA and indicated concentration of copper complex ( $20 \mu \mathrm{M}$ for incubations with MPA and $5 \mu \mathrm{M}$ for incubations with $\mathrm{H}_{2} \mathrm{O}_{2}$ ). Reaction was quenched after 15 minutes by addition of $10 \mathrm{mM}$ diethyl dithiocarbamic acid $(5 \mu \mathrm{L})$. DNA was isolated from the reaction mixture by ethanol precipitation and dried by lyophilization. Piperidine treatment was performed by adding $20 \mu \mathrm{L}$ of $0.2 \mathrm{M}$ piperidine to the dried DNA followed by incubation at $90^{\circ} \mathrm{C}$ for $30 \mathrm{~min}$. The DNA was then lyophilized, re-suspended in water, normalized to $45 \mathrm{nCi}$ per sample, mixed with loading buffer $(0.25 \%$ bromphenol blue, $0.25 \%$ xylene cyanole, $3 \%$ sucrose, and $7 \mathrm{M}$ urea), separated by denaturing PAGE $(20 \%, 7 \mathrm{M}$ urea) and visualized by autoradiography with a Phosphorimager. Quantification of the products relied on ImageQuant software.

\section{$\mathrm{O}_{2}$ Dependence of Strand Scission}

A solution containing OD1/OD2 (100 nM) and complex $\mathbf{1}(20 \mu \mathrm{M})$ was degassed by bubbling with prepurified nitrogen using a syringe needle for 15 min prior to addition complex 1 ( 5 $\mu \mathrm{M})$ and either MPA ( $5 \mu \mathrm{L}$, degassed) or $\mathrm{H}_{2} \mathrm{O}_{2}(2 \mu \mathrm{M})$ under standard reaction conditions. The mixture was kept under inert atmosphere by continually blanketing the sample with $\mathrm{N}_{2}$. 


\section{Strand Scission in the Presence of Radical Scavengers}

Quenching agents $10 \mathrm{mM}$ ethanol, D-mannitol, and tert-butanol were alternatively added to standard reaction mixtures. DNA oxidation was initiated by addition of either MPA or $\mathrm{H}_{2} \mathrm{O}_{2}$, quenched, and analyzed following the standard procedure described above.

\section{UV-Vis Spectroscopic Studies}

The dicopper(H) and dicopper(I) complexes of the ligands N3 -N5 (1 mM) were prepared by dissolving the respective perchlorate salts in dry and degassed methanol. The side-on peroxo complexes were generated as described in the literature by addition alternatively of excess dioxygento the dicopper(I) solution pre-cooled to $-80^{\circ} \mathrm{C}$ and excess $(10 \mathrm{mM}) \mathrm{H}_{2} \mathrm{O}_{2}$ and $\mathrm{Net}_{3}$ to a solution of pre-cooled $\left(-80^{\circ} \mathrm{C}\right)$ dicopper(II) complex. ${ }^{9-11}$

\section{Exogenous Substrate Oxidation}

The dicopper(I) complex $\left[\mathrm{Cu}_{2}{ }_{2}(\mathbf{N} 4)(\mathrm{MeCN})_{2}\right]\left(\mathrm{ClO}_{4}\right)_{2}{ }^{9}$ was prepared in a solution of $\mathrm{MeOH}$ $(\sim 1 \mathrm{mM}, 15 \mathrm{~mL})$ under anaerobic conditions in a glovebox and handled on the benchtop using standard Schlenk techniques. The solution was cooled to $-78^{\circ} \mathrm{C}$ with an acetone/dry ice bath and dry $\mathrm{O}_{2}$ gas was bubbled through the solutions for a few minutes allowing full formation of the peroxo-dicopper(II) complex $\left[\mathrm{Cu}^{\mathrm{II}}{ }_{2}(\mathbf{N} 4)\left(\mathrm{O}_{2}\right)\right]\left(\mathrm{ClO}_{4}\right)_{2} \cdot{ }^{9}, 10$ Excess $\mathrm{O}_{2}$ was then removed by three vacuum/Ar purge cycles, and $\mathrm{Ar}$ was also subsequently bubbled into the solutions for at least 60 seconds. Then, one equivalent of the internal standard (decane) and 10 equivalents of substrate (thioanisole or $\mathrm{N}, \mathrm{N}$-dimethylaniline) were added as a methanol solution. Argon was bubbled into the mixture again to remove any dissolved $\mathrm{O}_{2}$ and the reaction was allowed to proceed under argon for $20-24$ hours $\left(-78^{\circ} \mathrm{C}\right)$. The reaction solution was warmed to room temperature and pentane was added to precipitate the copper complex from the resulting green solution. The products in the supernatant were analyzed by gas chromatography (GC) under standard conditions. ${ }^{5 a}$ Reported yields represent an average of 5-6 independent determinations.

\section{Results and Discussion}

\section{Ligands and Complexes}

The homologous series of dicopper(II) complexes 1-3 (Figure 1) were synthesized in order to study the mechanistic details of DNA oxidation chemistry promoted by multinuclear copper complexes $\left[\mathrm{Cu}^{\mathrm{II}} 2(\mathbf{N n})\left(\mathrm{O}_{2}{ }^{2-}\right)\right]^{2+}$ which are otherwise known to form $\left[\mathrm{Cu}^{\mathrm{II}}{ }_{2}(\mathbf{N n})\left(\mathrm{O}_{2}{ }^{2-}\right)\right]^{2+}$ species from dicopper(I)/O $\mathrm{O}_{2}$ chemistry (see Introduction). The synthesis of $\mathbf{1 - 3}$ is described in the Experimental Section and X-ray quality crystals were obtained for $\left[\mathrm{Cu}_{2}{ }_{2}(\mathbf{N} 4)\right.$ $\left.\left(\mathrm{ClO}_{4}\right)_{2}\left(\mathrm{H}_{2} \mathrm{O}\right)_{2}\right]\left(\mathrm{ClO}_{4}\right)_{2} \cdot 2 \mathrm{H}_{2} \mathrm{O}(2)$ and $\left[\mathrm{Cu}_{2} \mathrm{II}(\mathbf{N 5})\left(\mathrm{NO}_{3}\right)_{4}\right] \cdot\left(\mathrm{CH}_{3} \mathrm{CN}\right)(\mathbf{3})$ (Figure 2). In both complexes, the copper centers are found in a distorted square pyramidal geometry. The perchlorate ion (acting as a unidentate ligand) occupies the axial position in complex $\mathbf{2}$ and possesses an expected elongated bond distance (e.g., Cul-O2 $=2.580(3) \AA$ ), with a water molecule (Cul-O1 $=2.039(3) \AA$ ) and the three nitrogen donors (two pyridines and one alkylamino $\mathrm{N}$ atom) from $\mathrm{N} 4$ occupying the basal plane. In 3 , one unidentate coordinated nitrate group on each copper(II) ion occupies an axial position (e.g., Cul-O1 $=2.304(13) \AA$, while the second nitrate and the three nitrogens from the ligand occupy the basal positions $(\mathrm{Cul}-\mathrm{N} \sim 2.02$ $\AA$ ). The pentacoordination observed for these complexes is typical for copper(II) ions. ${ }^{13}$

In both structures formed by the $\mathbf{N} \mathbf{4}$ or $\mathbf{N 5}$ binucleating ligands, the copper ions extend away from each other in the solid state. This seems to be the preferred geometry when there are no strong bridging ligands (i.e., $-\mathrm{OR}(\mathrm{R}=\mathrm{H} \text { or alkyl) or peroxide })^{14,15}$ or, for the case of dicopper (I) compounds $\left[\mathrm{Cu}_{2}{ }_{2}(\mathbf{N n})\right]^{2+},\left[\mathrm{Cu}_{2}(\mathbf{N n})\left(\mathrm{CH}_{3} \mathrm{CN}\right)_{2}\right]^{2+}$ or $\left[\mathrm{Cu}_{2} \mathrm{I}_{2}(\mathbf{N n})(\mathrm{CO})_{2}\right]^{2+.9,14}$ In aqueous solution, the fourth or fifth ligands for copper(II) in complexes 1-3 are presumably $\mathrm{H}_{2} \mathrm{O}$ 
or ${ }^{-} \mathrm{OH}$ and the weak counterions (perchlorate or nitrate) are not coordinated. It is important to note that in the presence of strong bridging ligand such as ${ }^{-} \mathrm{OR}(\mathrm{R}=\mathrm{H}$ or alkyl) or peroxide, the copper(II) ions in binuclear complexes with $\mathbf{N 3}, \mathbf{N 4}$ or $\mathbf{N 5}$ approach each other closely ( $<$ $3.6 \AA$ ) $.9-11,15$

\section{Reaction of Duplex DNA with Dicopper(Nn) Complexes in the Presence of MPA and $\mathrm{O}_{\mathbf{2}}$}

Duplex DNA (OD1/OD2) was treated with $\left[\mathrm{Cu}^{\mathrm{II}}{ }_{2}(\mathrm{Nn})\right]^{2+}(\mathbf{1}, \mathbf{n}=3 ; \mathbf{2}, \mathbf{n}=4 ; \mathbf{3}, \mathbf{n}=5)$ in the presence of excess MPA and then quenched with diethyldithiocarbamic acid in analogy to previous methods used to examine other bi- and trinuclear copper complexes. ${ }^{7,8}$ PAGE analysis revealed that direct and specific strand scission of the radiolabeled strand (OD1) was promoted by complexes $\mathbf{2}$ and $\mathbf{3}$ at one single-strand/double-strand junction (Figure 3, lanes 2 and 3). Quantification of the scission products by phosphorimage analysis revealed that on average $66 \%$ of the direct strand cleavage was targeted to three specific residues $G_{21}, G_{22}$, and $\mathrm{A}_{23}$. Neither MPA nor complex 2 alone produced any detectable strand scission (Figure 3, Lanes 5 and 6). A mononuclear analog, $\mathrm{Cu}^{\mathrm{II}}(\mathrm{MePY} 2)(\mathrm{MeCN})\left(\mathrm{ClO}_{4}\right)_{2}$ (4) (see diagram) of the Nn series 1-3 generated a low level of non-specific background cleavage of DNA with MPA/ $\mathrm{O}_{2}$ (Figure 3, lane 4). This observation is in line with our previous studies ${ }^{7}$ on a number of copper systems for which multi- but not mononuclear copper complexes are necessary, although not sufficient, to support DNA cleavage.

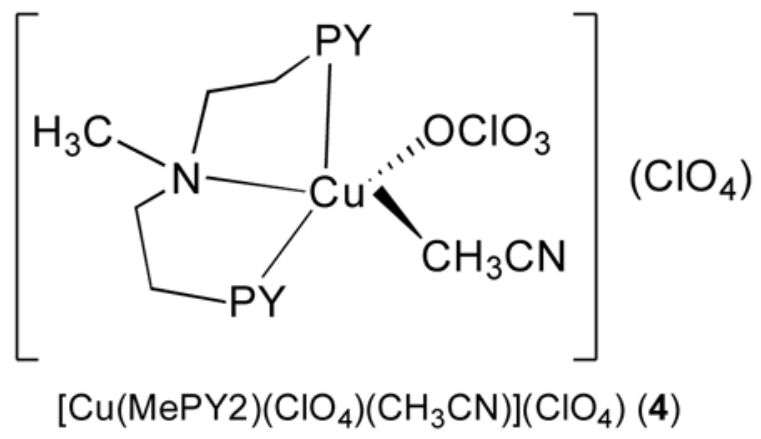

The properties of $\left[\mathrm{Cu}_{2} \mathrm{II}(\mathbf{N} 4)\left(\mathrm{ClO}_{4}\right)_{2}\left(\mathrm{H}_{2} \mathrm{O}\right)_{2}\right]\left(\mathrm{ClO}_{4}\right)_{2} \cdot 2 \mathrm{H}_{2} \mathrm{O}(\mathbf{2})$ and $\left[\mathrm{Cu}_{2} \mathrm{II}(\mathrm{N} 5)\left(\mathrm{NO}_{3}\right)_{4}\right]$. $\left(2 \mathrm{H}_{2} \mathrm{O}\right)(3)$ mimic the active bi- and trinuclear copper complexes described earlier. ${ }^{7}$ For each, direct strand scission predominated, and little enhancement of scission was observed after subsequent treatment with hot piperidine that induces scission at certain types of oxidized nucleobases (Figure S1, lane 1). ${ }^{3}$ Selective reaction by multinuclear copper complexes has always been localized to helix-coil junctions, ${ }^{7,8}$ and complexes $\mathbf{2}$ and $\mathbf{3}$ are no exception. Furthermore, strand scission has typically been dependent on the distribution of purines in the vicinity of the junction and limited to one of the two strands extending from the junction. ${ }^{7}$

Reaction of complex 2 was confined to the 3 '-extension of OD1 in the purine-rich junction of OD1/OD2 (Figure 3). The $5^{\prime}$-extension of this junction (OD2) was not a target of selective strand scission (Figure S2, lanes 6-8). ${ }^{5 a}, 6$ The alternative junction made from the 5 ' extension of OD1 and 3' extension of OD2 was also not a target of efficient reaction. Interestingly, the binuclear complex $\mathrm{Cu}_{2}{ }_{2}(\mathbf{N} 3)\left(\mathrm{H}_{2} \mathrm{O}\right)_{5}\left(\mathrm{ClO}_{4}\right)_{4}(\mathbf{1})$ yielded only non-specific background reaction, presumably due to a structural inadequacy of the complex of $\mathbf{N 3}$, compared to that of N4 or N5. The similarities in behavior, i.e., selective and efficient DNA oxidation, between previously studied compounds ${ }^{7}$ and $\mathbf{2}$ and $\mathbf{3}$ help support our choice of using the copper(Nn) series for correlating structure and reactivity of the multinuclear complexes with DNA. Such a comparison also provides the first opportunity to compare data on the $\mathrm{Cu}_{2} \mathrm{O}_{2}$ intermediates gathered at low temperature ${ }^{9-11}$ under non-polar conditions with those gathered under protic conditions. 


\section{Reaction of Duplex DNA with Dicopper(Nn) Complexes in the Presence of $\mathrm{H}_{2} \mathrm{O}_{2}$}

The general mechanism proposed previously to explain the efficient scission of DNA by multinuclear copper complexes involved initial reduction of the $\mathrm{Cu}$ (II) centers to $\mathrm{Cu}$ (I) followed by reaction with $\mathrm{O}_{2}$ to form a $\mathrm{Cu}_{2}{ }_{2} \mathrm{O}_{2}$ derivative. ${ }^{7} \mathrm{The} \mathrm{Cu}^{\mathrm{II}}{ }_{2} \mathrm{Nn}$ series was expected to react analogously. Peroxodicopper(II) complexes have been extensively studied and characterized. 5,6-16-21 They are typically generated in relatively non-polar organic solvents at temperatures below $0^{\circ} \mathrm{C}$ alternatively from reactions of mono or dicopper(I) complexes with $\mathrm{O}_{2}$ or by treatment of $\mathrm{Cu}$ (II) derivatives with $\mathrm{H}_{2} \mathrm{O}_{2}$ (Scheme 1). The $\mathrm{Cu}_{2}{ }_{2} \mathrm{Nn}$ series preferentially forms a side-on peroxo derivative under aprotic conditions from dicopper(I)/ $\mathrm{O}_{2} \cdot{ }^{9,11}$ If similar chemistry occurs under aqueous conditions and the resulting peroxodicopper(II) complex can effect DNA strand scission, then this same $\mathrm{Cu}_{2}{ }_{2} \mathbf{N n}$ series should also promote reactions with OD1/OD2 in the presence of $\mathrm{H}_{2} \mathrm{O}_{2}$ that are identical to those already detected in the presence of the more common MPA/O $\mathrm{O}_{2}$ (see Scheme 1).

Indeed, incubation of 5'-32 P-OD1/OD2 with complex 2 and $\mathrm{H}_{2} \mathrm{O}_{2}$ promoted strand scission with a selectivity identical to that observed in the alternative presence of $\mathrm{MPA} / \mathrm{O}_{2}$ (Figure 3, lane 2 vs Figure $4 \mathrm{~A}$ lane 2). ${ }^{22}$ Once again, complex 3 demonstrated equivalent activity as well (Figure 4A, lane 3), but complex 1 (Figure 4A, lane 1) and the mononuclear complex [Cu (MePY2) $\left.\left(\mathrm{CH}_{3} \mathrm{CN}\right)\left(\mathrm{ClO}_{4}\right)_{2}\right](4)$ remained inactive (Figure $\left.\mathrm{S} 3\right) .{ }^{23}$ Selective strand scission was limited as before to OD1 and its 3 '-extension from the helix-coil junction. No other selective reaction above the general background was observed for its 5 '-extension at the alternative junction nor from any region of OD2 (Figure S2). ${ }^{23}$ Treatment of the oxidized DNA with hot piperidine also did not significantly effect the selectivity or yield of strand scission (Figure SI). 23 The consistent selectivity and relative reactivity of the $\mathrm{Cu}_{2}{ }_{2} \mathrm{Nn}$ complexes under both conditions (i.e., MPA/ $\mathrm{O}_{2}$ or $\mathrm{H}_{2} \mathrm{O}_{2}$ ) suggest a common intermediate is responsible for DNA oxidation.

\section{DNA Strand Scission in the Presence and Absence of $\mathrm{O}_{2}$ and Radical Scavengers}

The $\mathrm{O}_{2}$-dependence of strand scission was expected to vary with respect to the oxidizing conditions used with dicopper complexes such as $\mathbf{2}$ as suggested in Scheme 1. Hydrogen peroxide alone should be sufficient to convert the dicopper(II) complexes $\mathrm{Cu}_{2}{ }_{2} \mathrm{Nn}$ to the proposed peroxodicopper(II) $\mathrm{Cu}_{2}{ }_{2} \mathrm{O}_{2}$ derivative, whereas $\mathrm{O}_{2}$ should be necessary to form the same intermediate from a reduced dicopper(I) precursor. ${ }^{5,6-9-11}$ Results with OD1/OD2 confirmed these predictions. Strand scission was greatly suppressed when $\mathrm{O}_{2}$ was removed from a reaction containing the reductant MPA and complex 2 (Figure 4B, lanes 1 vs. 2). In contrast, no $\mathrm{O}_{2}$-dependence was observed when $\mathrm{H}_{2} \mathrm{O}_{2}$ and complex 2 were used to oxidize DNA (Figure 4B, lanes 3 vs. 4). Such results provide further evidence for involvement of $\mathrm{Cu}_{2} \mathrm{O}_{2}$ as the common intermediate involved in DNA oxidation.

The limited distribution of scission products formed by complex $\mathbf{2}$ at the helix-coil junction of DNA provided the first suggestion that the ultimate oxidant generated under the reaction conditions was not freely diffusible. A variety of other copper complexes including mono-, biand trinuclear species had already been shown to act through reactive intermediates that were not affected by standard quenching agents for diffusible radicals such as hydroxyl radical. ${ }^{1}$,

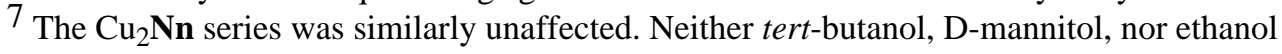
significantly inhibited selective strand scission at the DNA junction in the presence of complex 2. These results were consistent under both reaction conditions, MPA/O $\mathrm{O}_{2}$ and $\mathrm{H}_{2} \mathrm{O}_{2}$ (Figures $5 \mathrm{~A}$ and $5 \mathrm{~B}$ respectively). Again, similar responses were expected if a common oxidizing intermediate had formed. 


\section{Spectroscopic Evidence for Generation of a $\mathrm{Cu}_{2}-\mathrm{O}_{2}$ Intermediate and its Subsequent Oxidation of Substrates}

UV-Vis spectroscopy was used to gain direct evidence for a common oxidizing intermediate formed by the dicopper(II) complexes $\mathrm{Cu}_{2}{ }_{2} \mathrm{Nn}$ in the presence of $\mathrm{H}_{2} \mathrm{O}_{2}$. Reaction between each $\mathrm{Cu}_{2}{ }_{2} \mathrm{Nn}$ species, $\mathrm{H}_{2} \mathrm{O}_{2}$ and a base $\left(\mathrm{NEt}_{3}\right)(1: 10: 10)$ in methanol was consequently monitored over time at $-60^{\circ} \mathrm{C}$. Methanol was chosen as solvent for these model studies since the complexes remain in liquid solution at low temperature used to stabilize short-lived species. The protic nature of the solvent also allows for a reasonable comparison to aqueous conditions. A change in color from blue to yellow-brown was observed for complex $\left[\mathrm{Cu}_{2}{ }_{2}(\mathbf{N} 4)\right.$ $\left.\left(\mathrm{ClO}_{4}\right)_{2}\left(\mathrm{H}_{2} \mathrm{O}\right)_{2}\right]\left(\mathrm{ClO}_{4}\right)_{2} \cdot 2 \mathrm{H}_{2} \mathrm{O}(2)$ with concomitant appearance of a peak at $365 \mathrm{~nm}(\varepsilon=8500$ $\left.\mathrm{M}^{-1} \mathrm{~cm}^{-1}\right)$ and a broad shoulder at $452 \mathrm{~nm}\left(\varepsilon=2000 \mathrm{M}^{-1} \mathrm{~cm}^{-1}\right)$ (Figure 6B). ${ }^{24,25}$ Equivalent analysis of complex $\left[\mathrm{Cu}_{2}{ }^{\mathrm{II}}(\mathbf{N 5})\left(\mathrm{NO}_{3}\right)_{4}\right] \cdot\left(2 \mathrm{H}_{2} \mathrm{O}\right)(\mathbf{3})$ under the same conditions yielded a spectrum with a peak at $360 \mathrm{~nm}\left(\varepsilon=4600 \mathrm{M}^{-1} \mathrm{~cm}^{-1}\right)$ and a shoulder at $430 \mathrm{~nm}(\varepsilon=1050$ $\mathrm{M}^{-1} \mathrm{~cm}^{-1}$ ) (Figure 6C). These observations indicate that reaction of the dicopper(II) complexes $\mathrm{Cu}_{2}{ }_{2} \mathrm{Nn}(\mathrm{n}=4,5)$ with hydrogen peroxide indeed lead to side-on $\mu-\eta^{2}: \eta^{2}\left(\mathrm{Cu}_{2}{ }_{2}\left(\mathrm{O}_{2}{ }^{2-}\right)\right)$ complexes under protic conditions. The UV-Vis spectroscopic signatures formed under these conditions are identical to those detected after exposure of $\left[\mathrm{Cu}_{2}(\mathbf{N} 4)\left(\mathrm{CH}_{3} \mathrm{CN}\right)_{2}\right]^{2+}$ and $\left[\mathrm{Cu}_{2} \mathrm{I}_{2}(\mathrm{~N} 5)\left(\mathrm{CH}_{3} \mathrm{CN}\right)_{2}\right]^{2+}$ toO $_{2} .5 \mathrm{a}, 6,9,10,14,25$

Equivalent reaction of complex $\mathrm{Cu}_{2} \mathrm{II}_{2}(\mathbf{N} \mathbf{3})\left(\mathrm{H}_{2} \mathrm{O}\right)_{5}\left(\mathrm{ClO}_{4}\right)_{4}(\mathbf{1}), \mathrm{H}_{2} \mathrm{O}_{2}$ and $\mathrm{NEt}_{3}(1: 10: 10)$ did not yield a spectrum that corresponded to formation of a dicopper-side-on-peroxo complex in contrast to prior studies with the copper(I) derivative under aprotic conditions. ${ }^{9}$ Instead, a single peak at $343 \mathrm{~nm}\left(\varepsilon=5600 \mathrm{M}^{-1} \mathrm{~cm}^{-1}\right)$ was evident (Figure 6A). Based on the literature, 16-21 this spectrum can be ascribed to an unbridged $\mathrm{Cu}^{\mathrm{II}}-\mathrm{OOH}$ moiety (i.e., perhaps either $\left[\left(\mathrm{H}_{2} \mathrm{O}\right) \mathrm{Cu}^{\mathrm{II}}-(\mathbf{N} 3)-\mathrm{Cu}^{\mathrm{II}}(\mathrm{OOH})\right]^{3+}$ or $\left.\left[\mathrm{Cu}^{\mathrm{II}}{ }_{2}(\mathbf{N} 3)(\mathrm{OOH})_{2}\right]^{2+}\right) .5,8,26$ The inability of the $\mathbf{N} 3$ complex to oxidize DNA suggests that this type of end-on peroxo intermediate is incapable of promoting direct DNA strand scission in contrast to the side-on bridging peroxo intermediate formed by the $\mathbf{N} \mathbf{4}$ and $\mathbf{N} \mathbf{5}$ complexes. This initial correlation is consistent with the activity of another binuclear copper complex formed with the ligand $\mathrm{PD}^{\prime}-\mathrm{O} .{ }^{8}$ This alternative ligand stabilizes a hydroperoxide $\mathrm{Cu}^{\mathrm{II}}{ }_{2}-\mathrm{OOH}$ intermediate 8 and its dicopper complex promotes oxidation of guanine rather than direct strand scission at helix-coil junctions of DNA. The hydroperoxide $\mathrm{Cu}_{2}{ }_{2}-\mathrm{OOH}$ intermediate has additionally been shown recently to oxidize nitrile solvents under aprotic conditions. ${ }^{8}$ However, the $\mathbf{N} 3$ complex has not yet been detected to react with DNA in any capacity.

The potential role of the $\mu-\eta^{2}: \eta^{2}$-peroxodicopper(II) intermediate in DNA oxidation was next characterized in a model system to identify its competence for oxidizing small organic substrates. The $\mu,-\eta^{2}: \eta^{2}$-peroxodicopper(II) derivative of complex 2 was first generated in $\mathrm{MeOH}$ by reaction with $\mathrm{H}_{2} \mathrm{O}_{2}$. Rapid disappearance of the peroxodicopper(II) species was detected by absorbance at $365 \mathrm{~nm}$ in less than 2 minutes after addition of either thioanisole or $\mathrm{N}, \mathrm{N}$-dimethylaniline at $-78^{\circ} \mathrm{C}$. Product analysis by gas chromatography indicated formation of phenylmethylsulfoxide and $N$-methylaniline in $90 \%$ and $82 \%$ yields respectively (per dicopper complex). Thus, $\left[\mathrm{Cu}_{2}{ }_{2}(\mathbf{N} 4)\left(\mathrm{O}_{2}{ }^{2-}\right)\left(\mathrm{ClO}_{4}\right)_{2}\right]^{2+}$ can effect oxo-transfer to sulfur and oxidative N-dealkylation (thought to occur via initial hydrogen-atom abstraction) ${ }^{26}$ reactions.

\section{Conclusions}

A series of binuclear complexes formed by the Nn ligand series has now established a correlation between oxidative strand scission of DNA and formation of an side-on bridged peroxodicopper(II) intermediate. This species can be generated by $\mathrm{Cu}_{2}$ and $\mathrm{O}_{2}$ as well as $\mathrm{Cu}_{2} \mathrm{II}_{2}$ and $\mathrm{H}_{2} \mathrm{O}_{2}$ (Scheme 1), and both conditions lead to DNA reaction with equivalent chemical and structural specificity. Generation of an alternative $\mathrm{Cu}^{\mathrm{II}}{ }_{2}-\mathrm{OOH}$ moiety did not promote DNA oxidation under conditions examined in this work. For at least one previous 
example, the end-on hydroperoxide derivative instead promoted an alternate oxidation of guanine residues as described previously. ${ }^{8}$ Thus, subtle changes in ligand structure may guide future design of copper-based reagents for selective reaction with nucleic acids based on preferentially stabilizing a particular type of copper-oxygen intermediate.

\section{Supplementary Material}

Refer to Web version on PubMed Central for supplementary material.

\section{Acknowledgements}

This work was supported by the NIH (GM28962 to K.D.K. and GM47531 to S.E.R.).

\section{References}

1. Perrin, DM.; Mazmuder, A.; Sigman, DS. Progress in Nucleic Acid Chemistry and Molecular Biology. Cohn, W.; Moldave, K., editors. 52. Academic Press; New York/Orlando: 1996. p. 123-151. (b) Pyle AM, Barton JK. Prog Inorg Chem 1990;38:413-475. (c) Morrow JR, Iranzo O. Curr Opin Chem Biol 2004;8:192-200. [PubMed: 15062781]

2. Pogozelski WK, Tullius TD. Chem Rev 1998;98:1089-1107. [PubMed: 11848926]

3. Burrows CJ, Muller JG. Chem Rev 1998;98:1109-1151. [PubMed: 11848927]

4. (a) Tu C, Shao Y, Gan N, Xu G, Guo Z. Inorg Chem 2004;43:4761-4766. [PubMed: 15257606] (b) Park G, Tomlinson JT, Melvin MS, Day CS, Wright MW, Manderville RA. Organic Letters 2003;5:113-116. [PubMed: 12529118] (c) Gonzalez-Alvarez M, Alzuet G, Borrás J, Pitié M, Meunier B. J Biol Inorg Chem 2003;8:644-652. [PubMed: 12739108] (d) Frelon S, Douki T, Favier A, Cadet J. Chem Res Toxicol 2003;16:191-197. [PubMed: 12588190]

5. (a) Hatcher LQ, Karlin KD. J Biol Inorg Chem 2004;9:669-683. [PubMed: 15311336] (b) Shearer J, Zhang CX, Hatcher LQ, Karlin KD. J Am Chem Soc 2003;125:12670-12671. [PubMed: 14558790]

6. (a) Mirica LM, Ottenwaelder X, Stack TDP. Chem Rev 2004;104:1013-1045. [PubMed: 14871148] (b) Lewis EA, Tolman WB. Chem Rev 2004;104:1047-1076. [PubMed: 14871149]

7. (a) Humphreys KJ, Karlin KD, Rokita SE. J Am Chem Soc 2001;123:5588-5589. [PubMed: 11389647] (b) Humphreys KJ, Karlin KD, Rokita SE. J Am Chem Soc 2002;124:8055-8066. [PubMed: 12095349] (c) Humphreys KJ, Johnson AE, Karlin KD, Rokita SEJ. Biol Inorg Chem 2002;7:835842. (d) Humphreys KJ, Karlin KD, Rokita SE. J Am Chem Soc 2002;124:6009-6019. [PubMed: 12022834] (e) Ito T, Thyagarajan S, Karlin KD, Rokita SE. Chem Commun 2005:4812-4814.

8. (a) Li L, Karlin KD, Rokita SE. J Am Chem Soc 2005;127:520-521. [PubMed: 15643865] (b) Li L, Narducci Sarjeant AA, Vance MA, Zakharov LN, Rheingold AL, Solomon EI, Karlin KD. J Am Chem Soc 2005;127:15360-15361. [PubMed: 16262386] (c) Li L, Murthy NN, Telser J, Zakharov LN, Yap GPA, Rheingold AL, Karlin KD, Rokita SE. in preparation

9. Karlin KD, Haka MS, Cruse RW, Meyer GJ, Farooq A, Gultneh Y, Hayes JC, Zubieta J. J Am Chem Soc 1988;110:1196-1207.

10. Liang HC, Karlin KD, Dyson R, Kaderli S, Jung B, Zuberbuhler AD. Inorg Chem 2000;39:58845894. [PubMed: 11188519]

11. Pidcock E, Obias HV, Abe M, Liang HC, Karlin KD, Solomon EI. J Am Chem Soc 1999;121:1299_ 1308.

12. Ellman GL. Arch Biochem Biophys 1959;82:70-77. [PubMed: 13650640]

13. Hathaway, BJ. Comprehensive Coordination Chemistry. Wilkinson, G., editor. 5. Pergamon; New York: 1987. p. 533-774.

14. Karlin KD, Tyeklar Z, Farooq A, Haka MS, Ghosh P, Cruse RW, Gultneh Y, Hayes JC, Toscano PJ, Zubieta J. Inorg Chem 1992;31:1436-1451.

15. Karlin KD, Shi J, Hayes JC, McKown JW, Hutchinson JP, Zubieta J. Inorg Chim Acta 1984;91:L3L7.

16. (a) Osako T, Nagamoto S, Tachi Y, Kitagawa T, Itoh S. Angew Chem Intl Ed 2002;41:4325-4328. (b) Ohtsu H, Itoh S, Nagatomo S, Kitagawa T, Ogo S, Watanabe Y, Fukuzumi S. Inorg Chem 
2001;40:3200-3207. [PubMed: 11399193] (c) Itoh K, Hayashi H, Furutachi H, Matsumoto T, Nagatomo S, Tosha T, Tereda S, Fujinami S, Suzuki M, Kitagawa T. J Am Chem Soc 2005;127:52125223. [PubMed: 15810857]

17. Wada A, Harata M, Hasegawa K, Jitskawa K, Masuda H, Mukai M, Kitagawa T, Einaga H. Angew Chem Intl Ed 1998;37:798-799.

18. Kodera M, Kita T, Miura I, Nakayama N, Kawata T, Kano K, Hirota S. J Am Chem Soc 2001;123:7715-7716. [PubMed: 11481001]

19. Chen P, Fujisawa K, Solomon EI. J Am Chem Soc 2000;122:10177-10193.

20. Kitajima N, Fujisawa K, Moro-oka Y. J Am Chem Soc 1989;111:8975-8976.

21. Masuda H, Yamaguchi S. Science and Technology of Advanced Materials 2005;6:34-47.

22. Higher concentrations of $\mathrm{H}_{2} \mathrm{O}_{2}$ or copper result in considerable DNA degradation and yield poorer selectivity. 23

23. See Supporting Information.

24. This experiment was repeated with $5 \% \mathrm{H}_{2} \mathrm{O}$ in methanol to confirm its integrity in the presence of water.

25. The molar absorptivities ( $\varepsilon$ ) observed for these peroxo-dicopper(II) complexes in $\mathrm{MeOH}$ are low compared to the values observed from $\operatorname{dicopper}(\mathrm{I}) / \mathrm{O}_{2}$ reactions, most likely because of their incomplete formation. ${ }^{9-11}$

26. Shearer J, Zhang CX, Zahkharov LN, Rheingold AL, Karlin KD. J Am Chem Soc 2005;127:54695483. [PubMed: 15826184] 

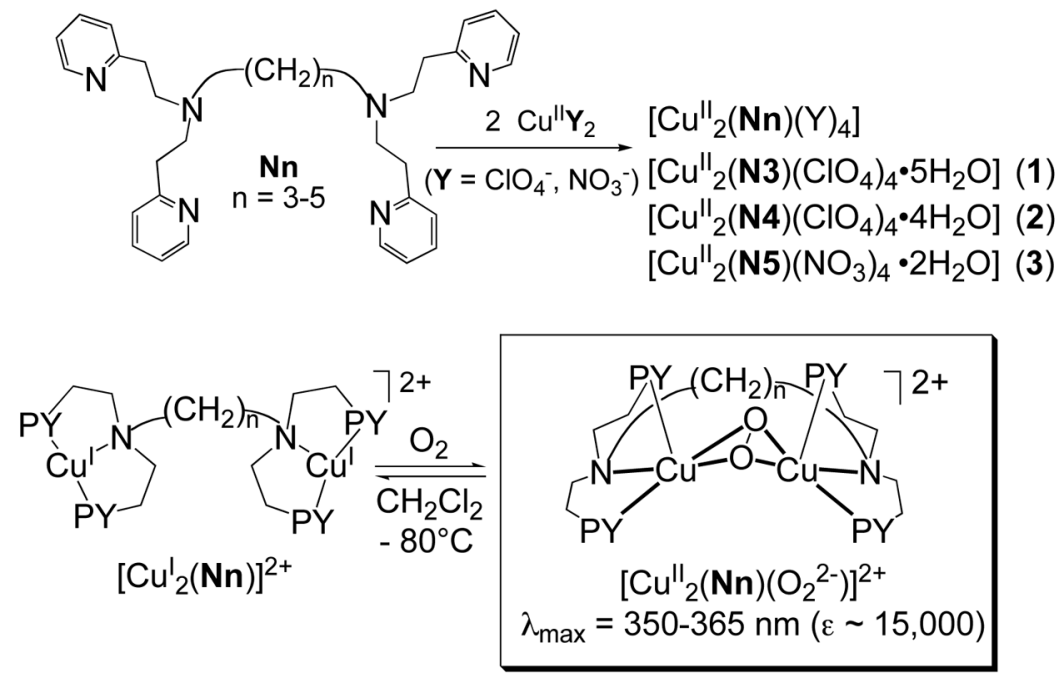

Figure 1.

Synthesis of complexes $\left[\mathrm{Cu}_{2}{ }_{2}(\mathrm{Nn})(\mathrm{Y})_{4}\right]\left(\mathrm{Y}=\mathrm{ClO}_{4}{ }^{-}\right.$or $\left.\mathrm{NO}_{3}{ }^{-}\right)$and known dioxygen chemistry of $\left[\mathrm{Cu}_{2}{ }_{2}(\mathrm{Nn})\left(\mathrm{CH}_{3} \mathrm{CN}\right)_{2}\right]^{2+}$ complexes $(\mathrm{n}=3-5)$. 

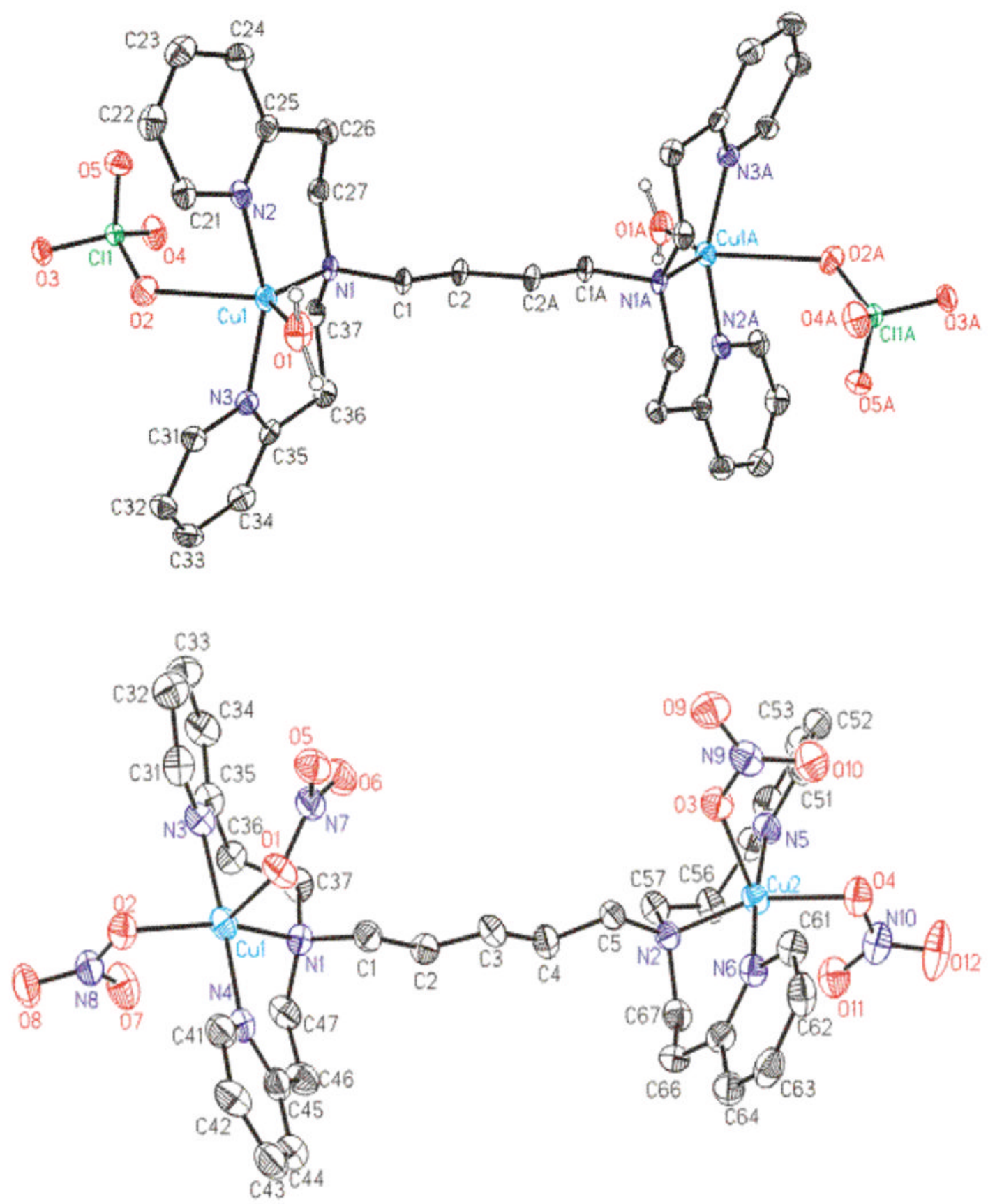

Figure 2.

ORTEP diagrams: $\left[\mathrm{Cu}_{2} \mathrm{II}_{2}(\mathbf{N} 4)\left(\mathrm{ClO}_{4}\right)_{2}\left(\mathrm{H}_{2} \mathrm{O}\right)_{2}\right]\left(\mathrm{ClO}_{4}\right)_{2} \cdot 2 \mathrm{H}_{2} \mathrm{O}(\mathbf{2})$ and $\left[\mathrm{Cu}_{2} \mathrm{II}_{2}(\mathbf{N 5})\left(\mathrm{NO}_{3}\right)_{4}\right]$. $\left(\mathrm{CH}_{3} \mathrm{CN}\right)(3)$. Selected bond distances $(\AA)$ for 2 : $\mathrm{Cu} 1-\mathrm{O} 1=2.039(3), \mathrm{Cu} 1-\mathrm{O} 2=2.580(3), \mathrm{Cu} 1-$ $\mathrm{N} 1=2.011(3), \mathrm{Cu} 1-\mathrm{N} 2=1.952(3), \mathrm{Cu} 1-\mathrm{N} 3=1.968(3) ; \mathrm{Cu} 1 \ldots \mathrm{Cu} 1 \mathrm{~A}=9.324 \AA$ A Selected bond distances $(\AA)$ for 3: Cul-O1 = $2.304(3), \mathrm{Cu} 1-\mathrm{O} 2=2.049(3), \mathrm{Cu} 1-\mathrm{N} 1=2.049(3), \mathrm{Cu} 1-\mathrm{N} 3=$ 2.002(4), Cul-N4 = 2.003(4); $\mathrm{Cu} 1 \ldots \mathrm{Cu} 2=10.707 \AA$. 


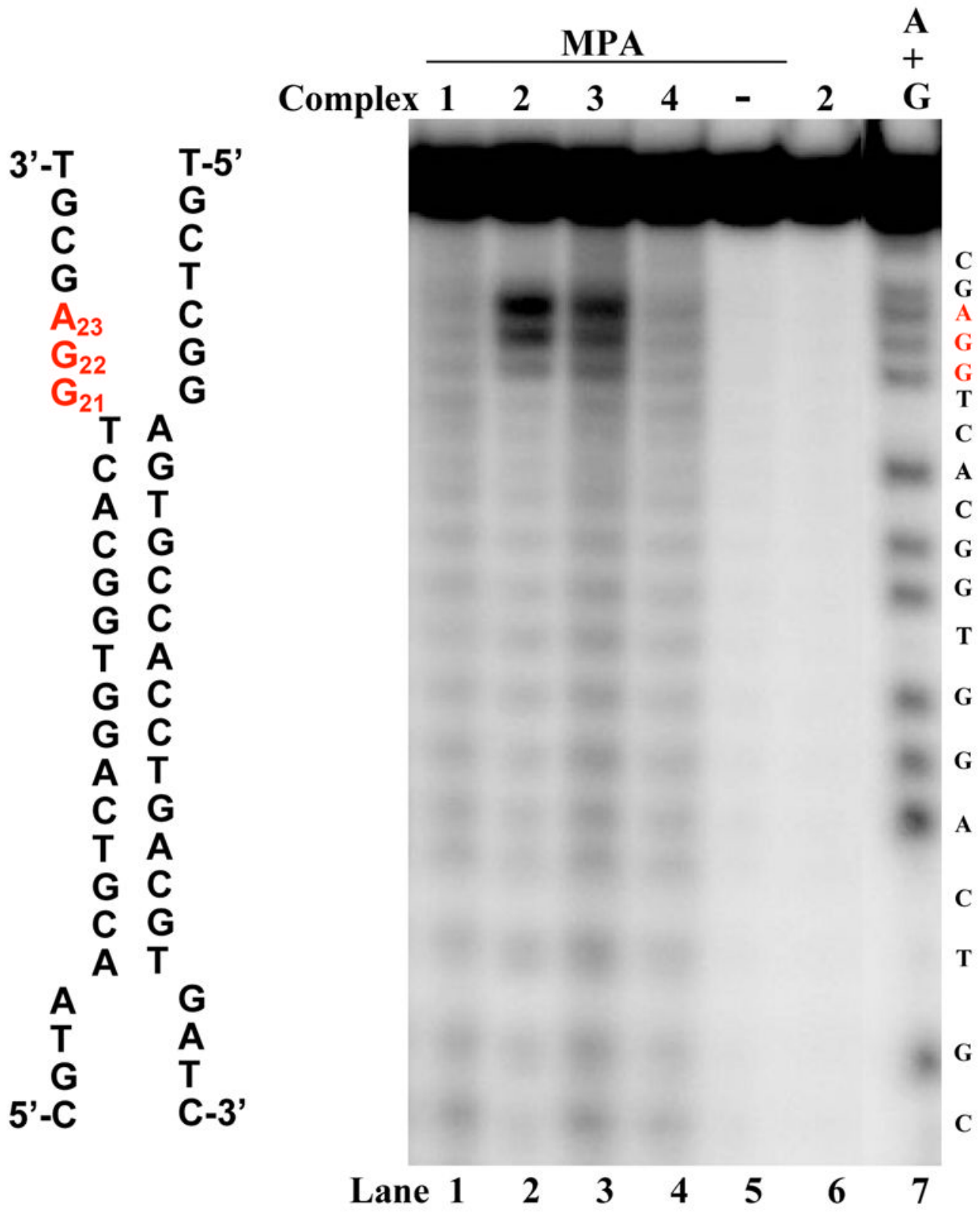

Figure 3.

Autoradiogram of a $20 \%$ polyacrylamide denaturing gel ( $7 \mathrm{M}$ urea) showing the products of direct strand scission from aerobic incubations (15 $\mathrm{min}$, ambient temperature) containing 100 $\mathrm{nM}$ 5'-32 P-OD1/OD2, $100 \mu \mathrm{M}$ MPA, sodium phosphate (10 mM, pH 7.5) and the indicated copper complexes. Lane 1: $20 \mu \mathrm{M}$ complex 1; lane 2: $20 \mu \mathrm{M}$ complex 2; lane 3: $20 \mu \mathrm{M}$ complex 3; lane 4: $40 \mu \mathrm{M}$ complex 4; lane 5: no copper complex; lane 6: $20 \mu \mathrm{M}$ complex 2 and no MPA; lane 7: A + G sequencing ladder. 
(A)

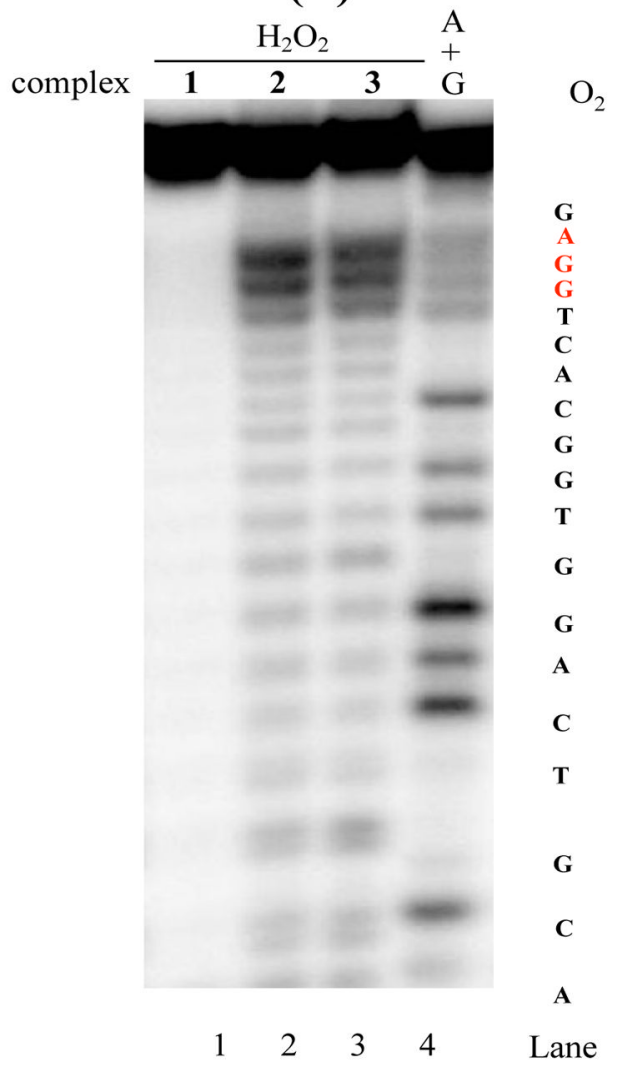

(B)

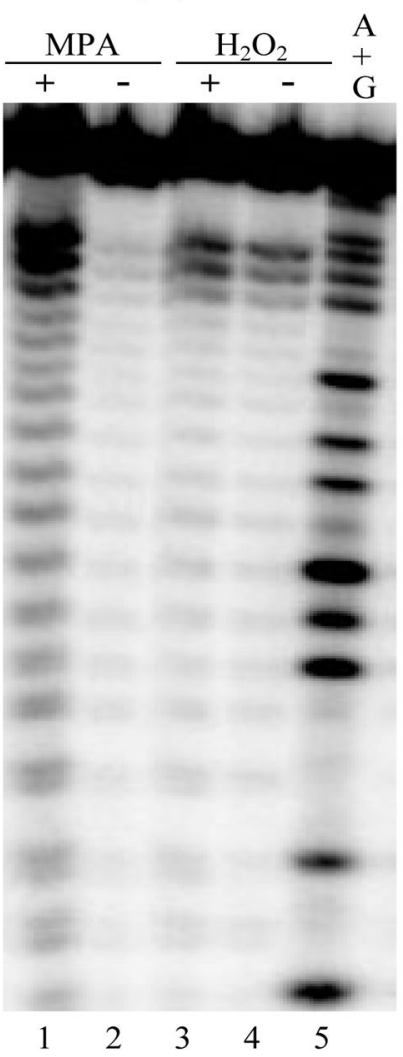

Figure 4.

Autoradiogram of a $20 \%$ polyacrylamide denaturing gel ( $7 \mathrm{M}$ urea) showing the products of direct strand scission from incubations ( $15 \mathrm{~min}$, ambient temperature) containing $100 \mathrm{nM}$ 5'-32 P-OD1/OD2, sodium phosphate (10 mM, pH 7.5) and the indicated copper complexes. (A) Reaction in the presence of $\mathrm{H}_{2} \mathrm{O}_{2}(2 \mu \mathrm{M})$ and copper complex $(5 \mu \mathrm{M})$. Lane 1: complex 1; lane 2: complex 2; lane 3: complex 3; lane 4: $\mathrm{A}+\mathrm{G}$ sequencing ladder. (B) $\mathrm{O}_{2}$-dependence of DNA strand scission promoted by complex 2 in the alternative presence of MPA $(100 \mu \mathrm{M})$ and $\mathrm{H}_{2} \mathrm{O}_{2}(2 \mu \mathrm{M})$. Lanes 1 and 2: complex $2(20 \mu \mathrm{M})$, MPA and $\mathrm{O}_{2}$ as indicated above; lanes 3 and 4: complex $2(5 \mu \mathrm{M}), \mathrm{H}_{2} \mathrm{O}_{2}$ and $\mathrm{O}_{2}$ as indicated above; lane 5: $\mathrm{A}+\mathrm{G}$ sequencing ladder. 


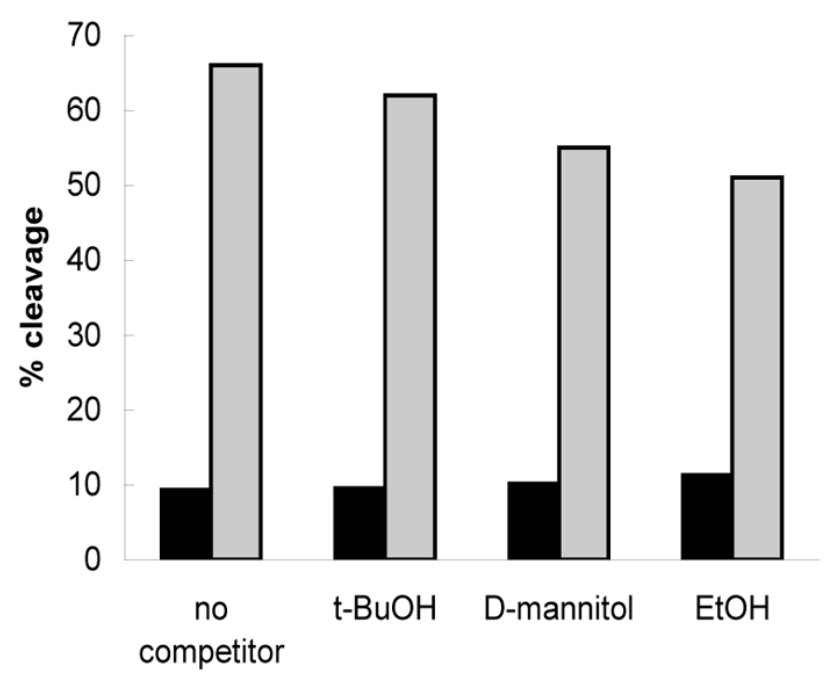

(A)

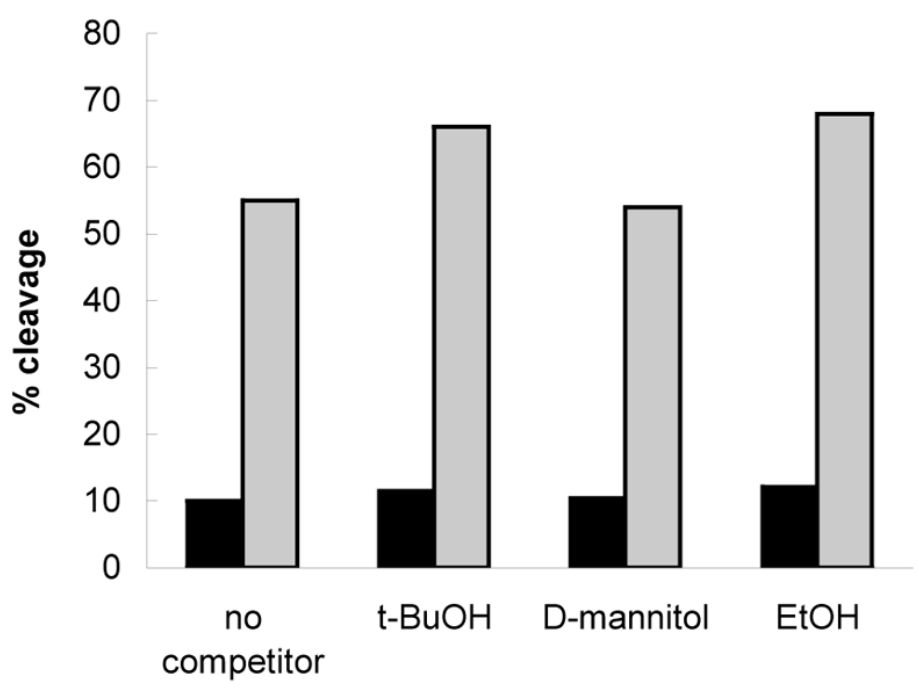

(B)

Figure 5.

Effect of radical scavengers on strand scission of $5^{\prime}-{ }^{32} \mathrm{P}-\mathrm{OD} 1 / \mathrm{OD} 2$ under standard conditions in the presence of (A) $20 \mu \mathrm{M}$ complex 2 and $100 \mu \mathrm{M}$ MPA or (B) $5 \mu \mathrm{M}$ complex 2 and $2 \mu \mathrm{M}$ $\mathrm{H}_{2} \mathrm{O}_{2}$ and the indicated scavenger $(10 \mathrm{mM})$. Total degradation of the DNA is designated by the darker shading and the percentage of specific strand scission at $A_{23}+G_{22}+G_{21}$ by the lighter shading. 
(A)

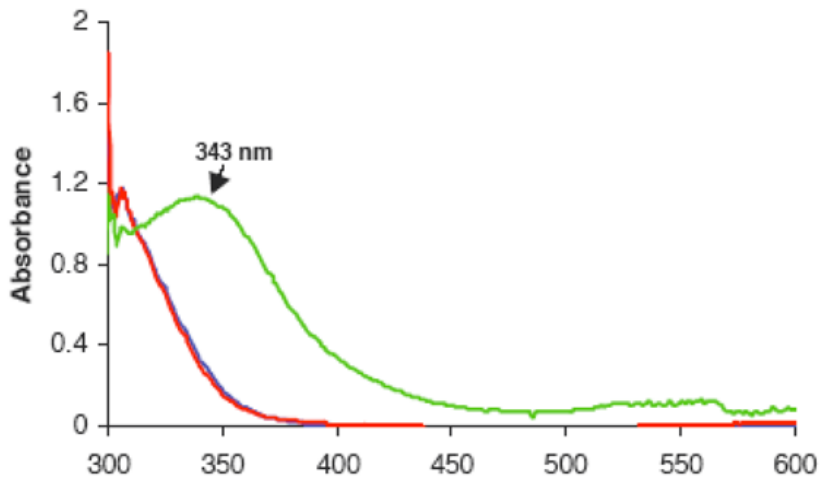

(B)

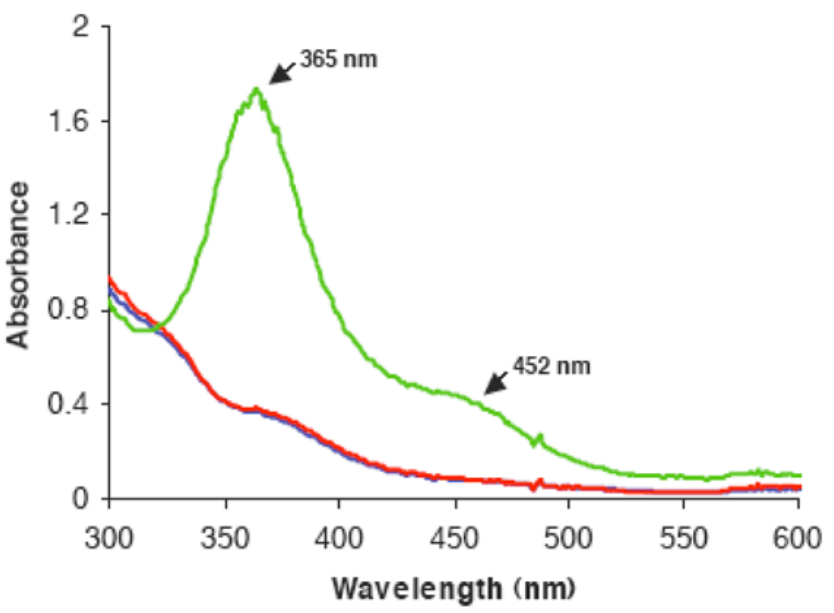

(C)

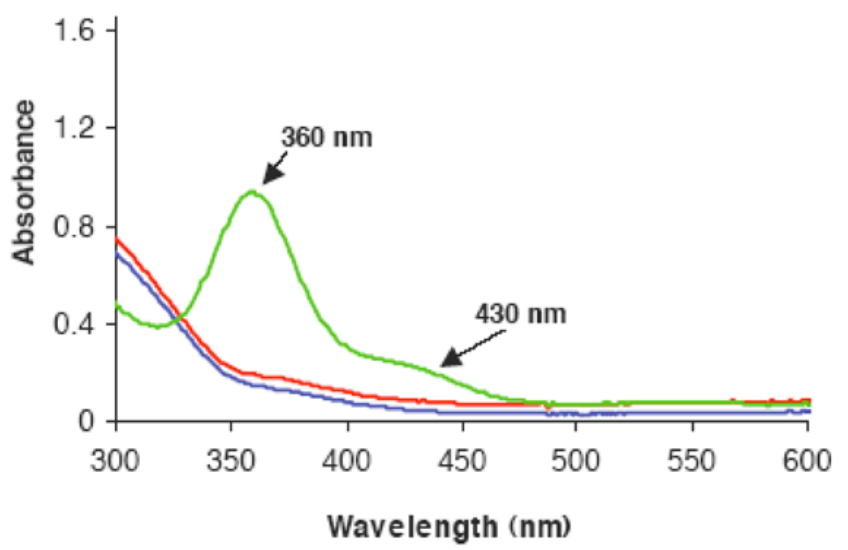

Figure 6.

UV-Vis spectra of the reaction of complexes 1 (A), 2 (B) and $\mathbf{3}(\mathrm{C})$ respectively with excess $\mathrm{H}_{2} \mathrm{O}_{2}$ and $\mathrm{NEt}_{3}$, (1: 10:10) recorded at $213 \mathrm{~K}_{\text {in }} \mathrm{CH}_{3} \mathrm{OH}:-1 \mathrm{mM}$ solution of copper(II) complex; - after addition of $10 \mathrm{mM} \mathrm{H}_{2} \mathrm{O}_{2}$; - after addition of $10 \mathrm{mM} \mathrm{NEt}_{3}$ 


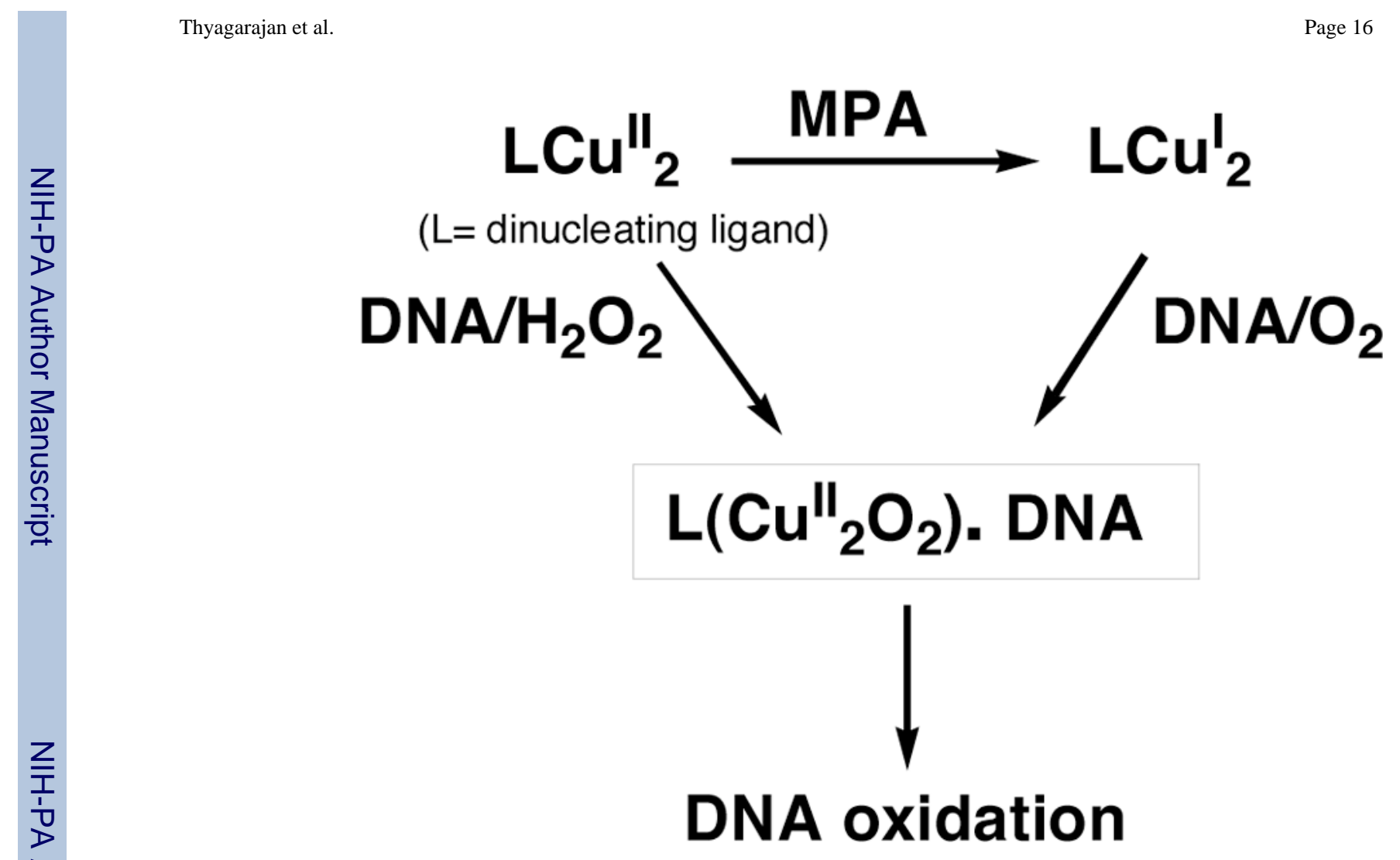

Scheme 1. 